\title{
DOKUMENTATION
}

\section{Andean Charter for the Promotion and Protection OF HUMAN RightS}

The Presidents of Bolivia, Colombia, Ecuador, Peru and Venezuela, meeting as the Andean Presidential Council and on behalf of the peoples of the Andean Community,

Drawing inspiration from the thought of The Liberator Simón Bolívar, who in his Address to the Constituent Congress of Bolivia proclaimed that it is the prime desire of all peoples to attain possession of their rights, exercise political virtues and facilitate to each person the acquisition of the luminous talents and enjoyment that belonging to the human race essentially entails;

Convinced that human rights are inherent to all human beings, who are all free and equal in dignity and rights;

Considering that the internal legal order of the States and International Law on Human Rights must protect human rights permanently and complementarily;

Committed to the respect and application of the Charter of the United Nations, the Charter of the Organization of American States, the American Convention on Human Rights - Pact of San José -, the International Covenant on Civil and Political Rights, the International Covenant on Economic, Social and Cultural Rights, the Additional Protocol to the American Convention on Human Rights in the area of Economic, Social and Cultural Rights - Protocol of San Salvador -, the Inter-American Democratic Charter and other international instruments on human rights to which the Andean nations are State Parties;

Engaged in the defense of the objectives and principles set forth in the Universal Declaration of Human Rights, the American Declaration on the Rights and Duties of Man and the United Nations Declaration on the Right to the Development;

Recognizing the contribution of the Andean Parliament and, in particular, the principles set forth in the Andean Social Charter adopted on September 30, 1994;

Committed to the development of the increasingly dynamic role played in today's world by the Andean Community, a conglomerate of peoples united by the conscience of a common past and geography and as a brotherhood in search of historical targets that affirm and project the roots and traditions characteristic of their identity;

Decided to consolidate and promote Andean unity based on the recognition of the diversity of their territories, peoples, ethnic groups and cultures, and with the firm belief that democracy, development and the respect of human rights and fundamental freedoms are interdependent and mutually reinforcing;

Bearing in mind the recommendations of the Andean Subregional Seminar «Democracy and Human Rights», held in Quito in August 2000, related to the drafting of an Andean Charter for the Promotion and Protection of Human Rights and cooperation to strengthen the observance of human rights in the Andean region; 
Taking note of the valuable contributions derived from the consultation process carried out to prepare this Charter with Andean Community bodies - in particular those received from the Court of Justice of the Andean Community and the Andean Labor Council - and representatives of civil society in the five Andean countries;

Determined to contribute towards advancing world solidarity and respect for human diversity based on the promotion and protection of human rights, and to promote the political, economic and social development of their countries, having as a focus and ultimate goal the welfare of the human being;

In compliance with the mandates of the Act of Carabobo, of June 24, 2001 and of the Declaration of Machu Picchu on democracy, the rights of indigenous peoples and the fight against poverty, of July 29, 2001, through which the Presidents of the Andean countries entrusted the Andean Council of Ministers of Foreign Affairs the preparation of a draft Andean Charter for the Protection and Promotion of Human Rights containing the principles and substantive issues of community policy on the subject;

Decided to jointly proclaim the principles, objectives and commitments of the Andean Community regarding the promotion and protection of human rights;

Sign this

\section{Andean Charter for the Promotion and Protection of Human Rights}

\section{SECTION I \\ GENERAL PRINCIPLES}

Article 1. The Member States of the Andean Community recognize that human rights are inherent to the nature and dignity of everyone.

Article 2. They recognize that all human rights must be enforceable and reaffirm their commitment to respect and command respect for human rights and the fundamental freedoms set forth in international instruments and in national legislations, and to adopt the necessary legal and administrative measures to prevent and investigate actions that may constitute violations of human rights, to ensure the effectiveness of constitutional and legal remedies, to try and punish those responsible for the violations and to grant full relief to the victims, according to law.

Article 3. They affirm the principle that all human rights and fundamental freedoms are universal, indivisible, interdependent and interconnected and that, consequently, the application, promotion and protection of civil and political rights as well as economic, social and cultural rights and the right to development must receive equal and decisive attention.

Article 4. Within the framework of respect for Human Rights, they reiterate the obligation and commitment of subregional states towards the preservation, protection and defense of democracy, as established among other instruments in the Riobamba Charter of Conduct, the Additional Protocol to the Cartagena Agreement "Commitment of the Andean Community to Democracy" and the InterAmerican Democratic Charter.

Article 5. They reiterate the will of the Andean Community Member States to accept the decisions of the Inter-American Human Rights Court. Furthermore, to take a constructive attitude to favorably accept the decisions and recommendations of regional and global non-jurisdictional mechanisms, when applicable, pursuant to relevant human rights treaties and constitutional provisions.

Article 6 . They ratify their commitment to promote conditions favorable to universal observance and strengthening of systems for the protection of human rights, through signature, ratification and/or 
accession to international human rights instruments, and harmonization between national legislations and international rules on the subject of human rights.

Article 7. They emphasize the need to promote the participation of civil society in the preparation and execution of Member States' national action plans and programs in favor of the observance of human rights.

Article 8. They declare that every person, whether a national or a foreigner, found within the territory of the Andean Community Member States is entitled to all human rights and fundamental freedoms set forth in International Law on Human Rights and in pertinent national legislation.

Article 9. They recognize the right of everyone to file accusations, complaints or petitions concerning violations of human rights and fundamental freedoms before judicial organs, Ombudsmen and/or pertinent administrative echelons, and to be heard under the terms provided for in national legislations; furthermore, they reaffirm their commitment to support judicial organs and Ombudsmen within the sphere of their jurisdiction.

\section{SECTION II \\ DISCRIMINATION AND INTOLERANCE}

Article 10. They reaffirm their decision to combat all forms of racism, discrimination, xenophobia and any kind of intolerance or exclusion against individuals or communities on account of race, color, sex, age, language, religion, public opinion, nationality, sexual orientation, immigration status or any other condition, and, decide to promote national legislations that punish racial discrimination.

Article 11. They shall strengthen educational plans and programs on human rights in order to promote a social culture based on tolerance, the respect of differences and non-discrimination.

Article 12. They agree to undertake the necessary actions to ensure the protection of the human rights of minorities and to combat all acts of discrimination, exclusion or xenophobia directed against, and affecting, them.

\section{SECTION III \\ DEMOCRACY AND HUMAN RIGHTS}

Article 13. The Andean peoples have a right to democracy and their governments have the obligation to promote and defend it, in order to achieve full exercise of all civil and political rights, economic, social and cultural rights, and the right to development.

Article 14. They reiterate their commitment to the contents of the Inter-American Democratic Charter and of Resolution 2002/46 of the United Nations Commission on Human Rights on "New measures to promote and consolidate democracy", especially regarding the essential elements of democracy: respect for human rights and fundamental freedoms, freedom of association, freedom of expression, of opinion, of access to and the exercise of power in accordance with the rule of law; the holding of periodic free, fair and impartial elections based on universal suffrage and secret balloting as an expression of the will of the population; a pluralistic system of political organizations and parties; the permanent, ethical and responsible participation of citizens in the political life of their countries; the separation and independence of powers; the transparency and accountability of public administration, and a free, independent and pluralistic press.

Article 15. They confirm their accession to the Commitment of the Andean Community to Democracy, signed in Porto in 1998, which is meant to become the Andean democratic clause. 
Article 16. They commit themselves to uphold democratic order in the Andean region, convinced that the observance of democratic values ensures the interdependency and mutual reinforcement between democracy, development and the respect for human rights and fundamental freedoms.

Article 17. They reiterate their commitment to the Inter-American Democratic Charter (2001), affirm that the observance of democratic order is an indispensable guarantee for the effective exercise of human rights and fundamental freedoms and, consequently, undertake to adopt all possible measures to strengthen it.

Article 18. They recognize the right of every citizen, man or woman, of the Andean Community Member States to elect and participate in the elections of the Andean Parliament, which shall be held through free, direct and secret universal suffrage.

\section{SECTION IV \\ CIVIL AND POLITICAL RIGHTS}

Article 19. They reaffirm their commitment to respect and safeguard civil and political rights, in particular the right to life and personal integrity, as set forth in the Covenant on Civil and Political Rights and international instruments on the subject as well as constitutional norms of Member States.

Article 20. They shall promote and protect the freedom of thought and of opinion and expression, in particular free operation of the media without public political interference or meddling of private pressure groups; the access to electronic information media; and the access of individuals to information that public administration and private corporations might have on them, as prescribed by law.

Article 21. They shall protect the right of everyone to seek asylum, pursuant to national and regional regulations in effect, and to enjoy its benefits in the event it is granted.

Article 22. They renew the commitment of the Andean Community Member States to apply the provisions of the International Covenant on Civil and Political Rights and of the American Convention on Human Rights concerning the safeguarding of human rights during periods officially declared "state of emergency", due to exceptional situations.

Article 23. They shall launch action plans with the participation of competent public entities and civil society, designed to prevent and eliminate, as well as investigate, try and punish, crimes against humanity, including the practice of torture and other cruel, inhuman or degrading treatment or punishment, the forced disappearance of persons and extrajudicial executions.

\section{SECTION V \\ ECONOMIC, SOCIAL AND CULTURAL RIGHTS}

Article 24. They reaffirm their commitment to comply with, and enforce compliance of, the rights and obligations set forth in the International Covenant on Economic, Social and Cultural Rights and, in particular, to take measures, either separately or through international assistance and cooperation, to the full extent of their resources, to progressively attain, through the appropriate means, the full exercise of the human rights recognized in the Covenant, including the right:

1. To have the opportunity to make a living through freely chosen or accepted work.

2. To enjoy just and satisfactory working conditions.

3. To form and join trade unions and to enjoy other labor rights.

4. To social security.

5. To protection and assistance for the family.

6. To an adequate standard of living for the individual and the families, including the rights to adequate food, clothing, and housing, and to the continued improvement of their living conditions. 
7. To the highest attainable standard of physical and mental health.

8. To education.

9. To culture and to enjoy the benefits of scientific advances and intellectual production.

Article 25. They shall promote and protect the rights and guarantees of workers, in accordance with national legislations, International Law on Human Rights and labor standards issued by the International Labour Organization.

Article 26. They highlight the relevance of the provisions of the Additional Protocol to the American Convention on Human Rights in the area of Economic, Social and Cultural Rights - Protocol of San Salvador - for the exercise of these rights in the Andean region and reiterate their commitment to perform the provisions of the Protocol in conjunction with those of other international instruments on the subject, and of their national legislations.

Article 27. They endorse the drafting of an optional protocol to the International Covenant on Economic, Social and Cultural Rights to enable the Economic, Social and Cultural Rights Committee to receive individual or collective complaints for possible violations of any of the rights set forth in the Covenant.

\section{SECTION VI \\ RIGHT TO DEVELOPMENT}

Article 28. They undertake to comply and enforce compliance with the principles set forth in the Declaration on the Right to Development (1986) of the United Nations General Assembly and in the international instruments containing provisions on this matter.

Article 29. In order to promote the right to development in the Andean sphere, they shall give priority to the attention of the following issues:

1. Creation of favorable conditions and the design of national and regional development policies with the purpose of progressively improving the social welfare of the Andean population, on the basis of its active, free and significant participation in development, with a view to the equitable sharing of its benefits.

2. National action and regional cooperation to eliminate the obstacles to development and the fight against poverty, extreme poverty and inequity; the promotion of an international economic order that addresses individual rights and the needs, conditions and aspirations of Andean countries and their access to the benefits of the global society.

3. Promotion of subregional, regional and international cooperation so that the impacts of scientific and technological progress are directed at the economic and social development of the nations and the strengthening of international peace and security, pursuant to the principles of the Charter of the United Nations.

4. Concerted action of Andean countries, in cooperation with other countries and groups of countries, to counterbalance the effects of the volatility of financial markets, ensure free access of our goods and services to international markets, and promote the elimination of dumping or subsidizing practices and policies and other hindrances to free trade.

5. Promotion of participation of the population in the decision-making process aimed at its sustainable human development.

6. Representation before international financial entities so that the design of structural adjustment policies and other measures related to foreign debt, takes into account their impact on the promotion and protection of human rights, in particular economic, social and cultural rights and the right to development, keeping in mind the conditions and social needs of the countries. 
7. National and regional governance of Andean countries so that: (a) international financial bodies and debtor countries consider effective relief mechanisms for foreign debt servicing, when required by the situation of the country concerned; and (b) creditor and debtor countries agree upon understandings to deal with the negative impacts that under given circumstances may arise from foreign debt servicing on the right to development.

8. Importance of conservation and protection of the environment and its appropriate use as a factor of sustainable development, particularly in relation to linking foreign debt and the environment.

\section{SECTION VII \\ RIGHT TO A SAFE AND PROTECTED ENVIRONMENT}

Article 30. They recognize the right of everyone and of societies to a safe and protected environment.

Article 31. They declare that the promotion and defense of the right to a safe and protected environment within the human rights regulatory framework requires taking into account the instruments of International Law on the environment, inter alia, the Convention on Biological Diversity, the Convention on Climate Change, the Convention to Combat Desertification, and in particular, the Regional Biodiversity Strategy for Countries in the Andean Tropics adopted by the Ministers of Foreign Affairs.

\section{SECTION VIII \\ RIGHTS OF INDIGENOUS PEOPLES AND COMMUNITIES OF AFRICAN DESCENT}

Article 32. They affirm that the Andean Community Member States are multiethnic and multicultural. The diversity of their societies is one of their cornerstones, wealth and basic characteristics; consequently, they reaffirm the right of all the peoples and communities in the Andean countries to the preservation and development of their own identities and the consolidation of each country's national unity based on the diversity of their societies.

Article 33. They particularly undertake to promote programs in favor of intercultural exchange, understood as the preservation and development of the ancestral identities of indigenous peoples and communities of African descent, through the fostering of social spaces for contact, dialog and interaction between such peoples and communities and the rest of societies in Andean countries, based on the reaffirmation and observance of their own identities and cultures

Article 34. They shall adopt effective measures so that educational systems, in all their levels and modalities, reflect the values inherent to the cultural and ethnic diversity of Andean countries and incorporate into their programs of study notions and practices that foster an attitude of respect for diversity and advance the purposes of intercultural exchange.

Article 35. They shall encourage educational systems to foster intercultural exchange through the development of specific programs for indigenous peoples - such as bilingual intercultural education and promote the establishment of study programs on indigenous and Afro-descendant cultures.

Article 36. They reiterate their commitment to fulfill and enforce fulfillment of the rights and obligations set forth in international instruments aimed at the promotion and protection of human rights of indigenous peoples and of communities of African descent, in particular the Convention (No. 169) concerning Indigenous and Tribal Peoples in Independent Countries of the International Labour Organization.

Article 37. They recognize that indigenous peoples and communities of African descent, in addition to the human rights their members are entitled to as individual citizens, are also entitled as human groups of ancestral roots, to collective rights, the common exercise of which promotes their historical continuity, the preservation of their identity and their future development. 
Article 38. They also recognize that indigenous peoples and communities of African descent, within the framework of national legislations and regulations on human rights, are entitled to maintain and develop their identities and customs in the cultural, spiritual, political, economic and legal spheres; to ownership and possession of the lands or territories they traditionally occupy; to not being displaced from them and to return to them in the event that they are; to preserve their own forms of social organization, exercise of authority and administration of justice; to develop and maintain their tangible and intangible cultural heritage; and to the protection of their ancestral collective knowledge and the exercise of their traditional practices.

Article 39. They further recognize the right of indigenous peoples and communities of African descent, within the framework of national constitutional order and legislations and international regulations on human rights, to preserve and promote their traditional practices for the conservation and sustainable use of biological diversity; to participate in the sustainable use, management and enjoyment of natural resources found within their lands or territories; to be consulted about decisions made concerning the exploitation of non-renewable natural resources found within their lands or territories and on any activity affecting the environment and their life styles; to share, whenever possible, the benefits derived from activities related to the management of natural resources within their lands and territories; to get equitable compensation for any damages sustained as a result of such activities; to be consulted and to participate in the drafting, application and evaluation of development plans concerning them; and to formulate their own sustainable development plans and take steps to obtain from the States resources for their funding and international assistance.

Article 40. They undertake to adopt the International Declaration on the Rights of Indigenous Peoples currently being drafted within the framework of the United Nations, and the Inter-American Declaration on the Rights of Indigenous Peoples, currently being drafted by the OAS, and express their support to the work of the Permanent Forum on Indigenous Issues of the United Nations Economic and Social Council.

Article 41. Recalling that the World Conference against Racism, Racial Discrimination, Xenophobia and Related Intolerance (Durban, South Africa, 2001) pointed out that indigenous peoples and communities of African descent have been the victims of discrimination, slavery and poverty, they express their commitment to design, promote and execute at the national, regional and international levels, strategies, programs and policies to promote an equitable social development and the full exercise of their human rights.

\section{SECTION IX RIGHTS OF GROUPS OBJECT OF SPECIAL PROTECTION A. RIGHTS OF WOMEN}

Article 42. They reiterate their commitment to fulfill and enforce fulfillment of the rights and obligations set forth in the International Convention on the Elimination of all forms of Discrimination against Women (1981) and its Optional Protocol (1999), the Convention on the Political Rights of Women (1954) and other international and regional instruments on the subject.

Article 43. They shall address the following main themes with a view to improving the promotion and protection of the human rights of women in their respective jurisdictions and in the Andean sphere:

1. Protection of women against discrimination - in the public and private spheres - with a view to safeguarding their human rights and in particular their right to life, integrity and personal safety, personal freedom, political participation, work, health and the exercise of sexual and reproductive rights, social security, adequate housing, education, ownership and participation in the economic life of society, and the access to effective legal and administrative remedies for violation of their rights. 
2. Adoption of programs to actively promote the participation of women in the public and private spheres of society, and the incorporation of the gender perspective in public policies and the promotion of this perspective in the private sector.

3. Actions to eradicate all forms of violence against women; to fight against impunity of those that commit it, in the public and private spheres; and to develop mechanisms to offer an effective compensation to the victims of gender-related violence.

4. Protection against sexual harassment and all forms of sexual and labor exploitation; slavery, trafficking of women and girls - particularly for sexual exploitation purposes -; and the incitement and forcing to engage in prostitution, forced pregnancies and sterilization.

5. Actions against all forms of discrimination against women in connection with marriage, consensual unions and family relations, especially with regard to the rights of women during marriage, consensual unions and after their dissolution, and with respect to housework, child rearing, the exercise of sexual and reproductive rights and the community property system.

\section{B. RIGHTS OF CHILDREN AND ADOLESCENTS}

Article 44. They reiterate their commitment to fulfill and enforce fulfillment of the rights and obligations set forth in the International Convention on the Rights of the Child (1989), its optional Protocols on the involvement of children in armed conflict (2000) and the sale of children, child prostitution and child pornography (2000), and other international instruments agreed to promote and protect the human rights of children and adolescents.

Article 45. They shall address the following main themes with a view to improving the promotion and protection of the human rights of children and adolescents in their respective jurisdictions and in the Andean sphere:

1. Attainment of equality of the rights of children and adolescents with respect to other members of society, in accordance with pertinent legislation, and the fight against all forms of discrimination against children on account of race, color, sex, language, religion, political opinion, nationality, age, economic and social condition, their immigration status or that of their parents, and any other condition.

2. Effective realization of the higher interest of children set forth in the Convention on the Rights of the Child, in the legal and institutional spheres.

3. Protection of the rights of children and adolescents to an identity and to keep such identity in confidence in those cases contemplated by the legislation; to have a name and a nationality; to have a legal representative; to know, to the extent possible, the identity of their parents and to be taken care of by them; and to be heard on subjects that concern them.

4. Protection of the fundamental rights of children and adolescents deprived of liberty, in accordance with national and international regulations on the subject.

5. Protection against slavery, trafficking, illicit moving and holding of children and adolescents abroad; and against the illegal or arbitrary deprivation of their liberty.

6. Eradication of child work following the elimination of all forms of labor exploitation based on the agreements of the International Labour Organization and applicable national legislations.

7. Protection against all forms of exploitation, sexual abuse and violence, including domestic violence, to which children may be subject, and implementation of the provisions of the optional Protocol to the Convention on the Rights of the Child related to the sale of children, child prostitution and child pornography (2000).

8. Combating impunity of those who affect the rights of children, in public and private spheres; and the development of programs to offer effective compensation to the victims of exploitation and violence. 
9. Prevention of, and punishment of those responsible for, the recruiting and involvement of children and adolescents in any armed conflict; respect for the minimum recruiting age of 18 years pursuant to the provisions of the optional Protocol to the Convention on the Rights of the Child related to the involvement of children in armed conflict (2000).

10. Adoption of a comprehensive social protection system aiming at addressing the economic, social and cultural rights of children and adolescents, the design and execution of which shall include the participation of civil society organizations involved in the promotion and protection of the rights of children.

11. The right of adolescents to receive adequate education and information for a responsible sexuality.

\section{RIGHTS OF OLDER ADULTS}

Article 46. They reiterate their commitment to fulfill and enforce fulfillment of the rights and obligations designed to promote and protect the human rights of older adults.

Article 47. They shall address the following main themes with a view to improving the promotion and protection of the human rights of older adults in their respective jurisdictions and in the Andean sphere:

1. Protection of older adults against all forms of discrimination and violence, including domestic violence.

2. Facilitation of opportune attention to older adults in public and private entities and services.

3. Participation of older adults and their organizations in decision-making on public issues concerning them.

4. Effective protection of the right of older adults to social security, particularly in connection with the rights and guarantees related to retirement.

5. Promotion of the participation and integration of older adults in society.

\section{RIGHTS OF PERSONS WITH DISABILITIES}

Article 48. They reiterate their commitment to fulfill and enforce fulfillment of the rights and obligations set forth in the United Nations Declaration on the Rights of Disabled Persons (1975); in international instruments designed to promote and protect the human rights of persons with disabilities, such as the Inter-American Convention in favor of Persons with Disabilities (1999); and in other declarations, resolutions and agreements on social protection adopted within the framework of the United Nations, the International Labour Organization, the World Health Organization and the Pan American Health Organization.

Article 49. They shall address the following main themes with a view to improving the promotion and protection of the human rights of persons with disabilities in their respective jurisdictions and in the Andean sphere:

1. Protection against all forms of discrimination and violence against persons with disabilities.

2. Prevention of causes originating disabilities, through education, safety in the workplace and public information.

3. Realization of the right to social security and health of persons with disabilities.

4. Fostering of personal development through programs that address the particular needs of persons with disabilities.

5. Social integration of persons with disabilities through work, education and full participation in their respective national communities. 
6. Facilitation of early assistance, medical treatment, rehabilitation, education, professional training and personal attention of persons with disabilities, with a view to their insertion in the working world under dignified and equitable conditions with respect to the rest of workers.

7. Information to the population on the rights of persons with disabilities in order to eliminate prejudice, stereotypes and discrimination, to which they are susceptible.

8. Drafting of architectural design programs in urban, rural and remote areas to enable better mobility and use of public spaces by disabled persons.

\section{E. RIGHTS OF MIGRANTS AND THEIR FAMILIES}

Article 50. They reiterate their commitment to fulfill and enforce fulfillment of the rights and obligations set forth in international instruments designed to promote and protect the human rights of migrants and their families; and affirm their intention to continue their efforts so that their national legislations enable the adoption of the International Convention on the Protection of the Rights of All Migrant Workers and Members of their Families (1990), and shall give priority to examining the possibility of signing, ratifying or accessing to it.

Article 51. They shall address the following main themes with a view to improving the promotion and protection of the human rights of migrants and their families in their respective jurisdictions and in the Andean sphere:

1. Respect for the right to migrate, to work, to free transit and circulation of migrants and their families, and the freedom to choose a residence, in accordance with national legislations and Community regulations.

2. Prevention and elimination of discrimination against Andean migrants and their families in access to public education and health services, housing and lodging, social security and employment; and creation of information and assistance centers for migrants.

3. Provision of identity papers to migrants and their families, without discrimination on account of race, color, sex, age, language, religion, nationality, political opinion, sexual orientation and immigration status.

4. Reunification of migrants and their families in the country of destination and regularization of their immigration status through the corresponding legal and administrative means.

5. Protection of the family members of migrants, especially children, adolescents and older adults, who continue living in their countries of origin and have become separated from their family members as a result of the migration.

6. Joint action of Andean Community countries to promote and protect the rights of migrants and their families before other countries and groups of countries, as well as in international and regional forums.

\section{F. RIGHTS OF PEOPLE WITH DIFFERENT SEXUAL ORIENTATION}

Article 52. They recognize that all persons, regardless of their sexual orientation or preference, have equal human rights.

Article 53. They shall combat all forms of discrimination against individuals on account of their sexual orientation or preference, in accordance with national legislations, and to this end, shall pay special attention to the prevention and punishment of violence and discrimination against persons with different sexual orientation or preference, and to guarantee legal remedies for effective compensation for damages derived from such offenses. 


\section{G. RIGHTS OF INTERNALLY DISPLACED PERSONS}

Article 54. They reiterate their commitment to fulfill and enforce fulfillment of relevant norms set forth in human rights instruments, International Humanitarian Law and International Law on Refugees designed to protect persons that are forced or compelled to leave their homes or their habitual place of residence, in particular to avoid the effects of armed conflict, situations of generalized violence, mass violations of human rights or natural or man-induced catastrophes, and who have not crossed over an internationally recognized state border.

Article 55. With a view to protecting the human rights of internally displaced persons in their respective jurisdictions and in the Andean sphere, they shall address the following priorities:

1. They shall monitor the application by public authorities of the United Nations "Guiding Principles on Internal Displacement" (1998), and promote their incorporation into the legislation of each country.

2. They shall guarantee the equality of rights between internally displaced persons and the rest of their countries' population, and investigate, try and punish those that violate the rights and fundamental freedoms of displaced persons.

3. They shall provide protection and humanitarian aid to internally displaced persons and/or facilitate the delivery of humanitarian aid by international or non-governmental organizations, in accordance with applicable international and national regulations.

4. They shall endeavor to establish the conditions and provide the means for the voluntary return of internally displaced persons, in safety and dignity, to their habitual place of residence, or their voluntary resettlement in other parts of the country.

\section{H. RIGHTS OF PERSONS DEPRIVED OF LIBERTY}

Article 56. They reiterate their commitment to fulfill and enforce fulfillment of the rights and obligations set forth in international instruments with respect to persons deprived of liberty.

Article 57. They shall address the following main themes, with a view to safeguarding the human rights of persons deprived of their liberty:

1. Implementation of programs designed to significantly improve living conditions in detention and penitentiary centers in each Member State, so that they conform to United Nations principles and regulations applicable to persons subject to any form of imprisonment or detention, in particular with regard to physical separation between indicted and convicted prisoners.

2. Adoption of measures aimed at avoiding violations of the human rights of detainees, inter alia, education and training of penitentiary personnel on the subject, and investigation, trial and punishment of those that commit such violations.

3. Creation of programs on rehabilitation and social reinsertion of persons deprived of their liberty, attached to penitentiary centers, and consideration of establishing in their legislations sentences alternative to confinement, such as the provision of community work and services.

4. Application of the principle of procedural celerity as a priority in the administration of justice, and trial and sentencing respecting the terms established in national legislations.

\section{HUMAN RIGHTS AND THE RIGHTS OF REFUGEES AND STATELESS PERSONS}

Article 58. They reiterate their commitment to fulfill and enforce fulfillment of the rights and obligations set forth in international instruments designed to promote and protect the rights of refugees and stateless persons, to which Andean Community Member States are a Party, in accordance with national legislations. 
Article 59. They shall address the following main themes, with a view to improving the promotion and protection of the human rights of refugees and stateless persons:

1. Protection of refugees and stateless persons against all forms of discrimination and violence on account of their race, color, sex, language, religion, political opinion, nationality, sexual orientation, immigration status, age or any other condition.

2. Access to education, social and health services, housing and work, and the right to free circulation, freedom of expression and religion and to the provision of proper documentation without any distinction whatsoever in the receiving country.

3. Effective enjoyment of their rights, in accordance with national legislations, in particular the right to life, security, ownership, to rely on effective remedies in front of the violation of their rights, respect of the standards of due process before the courts of the receiving country, to not being expelled - save in accordance with the law, but never to the country where their lives, security or liberty are threatened.

\section{SECTION X \\ OTHER SPHERES OF PROTECTION OF HUMAN RIGHTS}

Article 60. They recognize that the development of International Law on Human Rights leads to the consideration of other subjects related to the promotion and protection of such rights, and that Andean Community Member States should encourage this legal dynamic in the national and international spheres and work jointly to advance the regulatory development of human rights.

\section{SECTION XI \\ HUMAN RIGHTS AND INTERNATIONAL HUMANITARIAN LAW}

Article 61. They reaffirm their strong support for the rules of International Humanitarian Law set forth, inter alia, in the Geneva Conventions of 1949 and their 1977 Additional Protocols; reiterate their belief that these are the applicable international instruments to ensure a better protection of victims of international and non-international armed conflicts, and particularly of the civil population. They urge the parties in international and non-international armed conflicts to abide by the applicable rules of international humanitarian law.

Article 62. Within the context of legal development of International Law on Human Rights, they recognize the importance of its connection with International Humanitarian Law, in that the latter may be an instrument for its interpretation; and endorse the rules set forth in international conventions on these matters.

\section{SECTION XII \\ HUMAN RIGHTS PROMOTION AND PROTECTION MECHANISMS}

Article 63. They declare that the Andean Charter for the Promotion and Protection of Human Rights is the first comprehensive manifestation of the Andean Community on the subject of human rights in the Community sphere, and that it complements national, international and universal regulations thereon. Any program prepared within the framework of the provisions set forth in the Charter shall be coordinated with national activities, or those performed through international cooperation by Member States in the Andean region.

\section{NATIONAL MECHANISMS \\ A. ADMINISTRATION OF JUSTICE}

Article 64. For the promotion and protection of human rights in general, and the right to due process in particular, they shall encourage Andean Community Member States to rely on the efficient, independent, impartial and autonomous administration of justice. 
Article 65. They shall endorse directly and, as appropriate, in coordination with each nation's Judicial Service, the execution of programs designed to improve their justice administration systems, so as to, inter alia, promote the efficiency and transparency of legal procedures; combat acts of judicial corruption, unjustified delays in the administration of justice and abuse of preventive imprisonment; and offer solutions to the situation of non-convicted prisoners.

Article 66. They highlight the important role of the Administration of Justice in each Andean Community Member State for the protection of human rights through the application of national laws and international instruments.

Article 67. They support, in accordance with national legislations, the independent and autonomous performance of the Administration of Justice to investigate, try and punish those responsible for violations of human rights and to order the compensation of damages to victims of such violations

Article 68. They decide to promote legislative initiatives in order to harmonize national legislation with international regulations on human rights and to offer legal remedies at the national level for the protection of such rights.

Article 69. They recognize the right of every person to resort to international mechanisms for the protection of human rights, respecting the subsidiary nature of such mechanisms.

\section{B. OMBUDSMEN'S OFFICES}

Article 70. They recognize the role of Ombudsmen's Offices as institutional guarantees for the protection of human rights, and commit themselves to respect the constitutive statutes and legal prerogatives of Ombudsmen's Offices.

Article 71. They recommend the exchange of information and experiences among Andean Community Ombudsmen's Offices, in order to foster more effective management and coordination of their offices.

Article 72. They invite Ombudsmen's Offices to promote mechanisms that enable the realization of the right of the people to information on the activities of public institutions, in accordance to legal provisions and with the participation of organized civil society.

\section{ADVOCATES OF HUMAN RIGHTS}

Article 73. They reiterate the commitment of Andean Community Member States to the protection of the human rights of human rights advocates and the legitimacy of their work, in accordance with the provisions of the "Declaration on the Right and Responsibility of Individuals, Groups and Organs of Society to Promote and Protect Universally Recognized Human Rights and Fundamental Freedoms" (1999), and their will to cooperate with civil society in the promotion and protection of human rights within each country and at the regional level.

Article 74. They declare their commitment to respect the autonomy and independence of human rights advocates, to facilitate access to information they are legally entitled to, to provide full protection for the performance of their activities when required, and to firmly and effectively investigate, try and punish all acts that threaten the fundamental freedoms and guarantees that protect human rights advocates and their organizations.

\section{HUMAN RIGHTS PLANS AND PROGRAMS}

Article 75. They welcome the recommendation of the World Conference on Human Rights, held in Vienna (1993), and of other international meetings and forums, that each country should have a National Human Rights Plan. 
Article 76. They declare their commitment to encourage the participation of the people and of organizations of human rights advocates in the drafting, implementation and follow-up of National Human Rights Plans, and to make their reports on the implementation of such National Plans known to public monitoring institutions, civil society and the Andean Community Member States, through the General Secretariat.

Article 77. They encourage steps by Member States to obtain bilateral cooperation and the cooperation of multilateral bodies related to human rights, among them, the United Nations Office of the High Commissioner for Human Rights, in order to prepare national plans and programs on human rights or update existing ones.

\section{E. HUMAN RIGHTS AND LAW ENFORCEMENT AGENCIES}

Article 78. They affirm that the full observance of human rights requires the necessary action of law enforcement agencies to ensure that citizen security and public order are implemented under the principle of legality and respect for human rights.

Article 79. They shall establish cooperation channels among national law enforcement agencies of Member countries, in order to develop activities aimed at the promotion of human rights values in such institutions and the training of their personnel in due respect for the principle of legality, and, in the event of internal conflicts, in the rules of international humanitarian law.

\section{INTERNATIONAL MECHANISMS \\ A. COOPERATION WITH HUMAN RIGHTS TREATY MONITORING BODIES}

Article 80. They reaffirm their will to submit in due time the periodic reports that Andean Community Member Countries must present to bodies monitoring the implementation international human rights treaties. Participation of civil society in the report preparation and follow-up process shall be encouraged.

Article 81 . They shall evaluate and, wherever pertinent, give consideration to the final observations of international human rights treaty monitoring bodies following examination of periodic reports of Member countries, and shall give periodic reports and final observations the widest possible dissemination.

\section{B. COOPERATION WITH THE UNITED NATIONS AND INTER-AMERICAN SYSTEMS FOR THE PROMOTION AND PROTECTION OF HUMAN RIGHTS}

Article 82. They shall cooperate actively with the United Nations and Inter-American systems for the protection and promotion of human rights, and foster cooperation between both systems.

Article 83. They highlight the importance of the recommendations of the Inter-American Commission on Human Rights and reiterate their commitment to comply with the decisions and resolutions of the Inter-American Court of Human Rights.

\section{INTERNATIONAL CRIMINAL COURT}

Article 84. In view of its significance for International Law on Human Rights, they highlight the entry into force of the Rome Statute that creates the International Criminal Court, which, bearing in mind its supplementary and subsidiary nature with respect to national jurisdictions, shall contribute towards the fight against impunity of those responsible for genocide, crimes against humanity, war crimes and aggression.

Article 85. They undertake to consider, favorably and promptly, the ratification of the Statute of the International Criminal Court, for which they shall adjust their national legislations. 


\section{SECTION XIII \\ FOLLOW-UP OF THE ANDEAN CHARTER FOR THE PROMOTION AND PROTECTION OF HUMAN RIGHTS}

Article 86. They agree to promote the principles and objectives of the Andean Charter for the Promotion and Protection of Human Rights through the mechanisms mentioned in this section, without prejudice to the future incorporation of other follow-up ways and means through the pertinent Community channels.

Article 87. The Andean Council of Ministers of Foreign Affairs shall be the top community body in charge of the follow-up of subregional initiatives provided for in the Charter.

Article 88. The General Secretariat of the Andean Community shall provide the assistance required by the Andean Council of Ministers of Foreign Affairs to enable compliance with the provisions of the preceding Article.

Article 89. The Andean Council of Ministers of Foreign Affairs shall agree with the Andean Parliament on consultation mechanisms related to the contribution of this body to the implementation and follow-up of the Andean Charter for the Promotion and Protection of Human Rights.

Article 90. They invite the Ombudsmen from Andean Community Member States to follow-up and monitor the application of Andean Charter provisions that concern their powers and to meet in order to agree on the opinions and recommendations that they shall present to the Andean Council of Ministers of Foreign Affairs on the subject, through the General Secretariat.

Article 91. They invite civil society in Andean countries, and in particular human rights advocacy organizations, to take part in follow-up activities of the Andean Charter for the Promotion and Protection of Human Rights, in coordination with the General Secretariat and the Ministers of Foreign Affaires of Member States.

Article 92. For the follow-up of the Andean Charter for the Promotion and Protection of Human Rights and in addition to the activities set forth therein, the Andean Community countries shall organize regional programs to disseminate the principles of the Andean Charter, foster an Andean culture of respect for human rights, in particular the rights of individuals and groups of individuals requiring special protection, and to encourage the development of International Law on Human Rights in new spheres, as provided for in SECTION X of the Andean Charter.

Article 93. They recommend that National Human Rights Plans and other programs established for the protection of human rights take into consideration the contents and provisions of the Andean Charter for the Promotion and Protection of Human Rights, and that they coordinate, as possible, national activities with those derived from the application and follow-up of the Andean Charter.

\section{SECTION XIV GENERAL PROVISIONS}

Article 94. Nothing in the provisions of this Charter may be construed to limit the enjoyment and exercise of any right or freedom that may be recognized in accordance with the laws of any of the Member States or with international human rights instruments in effect in them.

Article 95. They agree to adopt the Andean Charter for the Promotion and Protection of Human Rights in the Spanish language and to translate it into the main ancestral languages of indigenous peoples in the Andean countries. 


\section{SECTION XV \\ FINAL PROVISION}

Article 96. They instruct their Ministers of Foreign Affairs, given the dynamics of the evolution of International Law on Human Rights, to review every four years the contents of this Charter to the effect of updating and improving it.

The Andean Council of Ministers of Foreign Affairs shall decide in due time upon the binding nature of this Charter.

Done and signed in Guayaquil, on the twenty-sixth day of July, two thousand and two.

\section{JORGE QUIROGA RAMIREZ}

President of the Republic of Bolivia

ANDRES PASTRANA ARANGO

President of the Republic of Colombia

GUSTAVO NOBOA BEJARANO

President of the Republic of Ecuador

ALEJANDRO TOLEDO MANRIQUE

President of the Republic of Peru

HUGO CHAVEZ FRIAS

President of the Bolivarian Republic of Venezuela 